\title{
In-house validation of a liquid chromatography tandem mass spectrometry method for the analysis of lipophilic marine toxins in shellfish using matrix-matched calibration
}

\author{
Arjen Gerssen - Erik H. W. van Olst • \\ Patrick P. J. Mulder • Jacob de Boer
}

Received: 15 April 2010/Revised: 26 May 2010/Accepted: 27 May 2010 /Published online: 16 June 2010

(C) The Author(s) 2010. This article is published with open access at Springerlink.com

\begin{abstract}
A liquid chromatography tandem mass spectrometry (LC-MS/MS) method for the quantitative analysis of lipophilic marine toxins in shellfish extracts (mussel, oyster, cockle and clam) was validated in-house using European Union (EU) Commission Decision 2002/657/EC as a guideline. The validation included the toxins okadaic acid (OA), yessotoxin (YTX), azaspiracid-1 (AZA1), pectenotoxin-2 (PTX2) and 13-desmethyl spirolide-C (SPX1). Validation was performed at $0.5,1$ and 1.5 times the current EU permitted levels, which are $160 \mu \mathrm{g} \mathrm{kg}^{-1}$ for OA, AZA1 and PTX2 and 1,000 $\mu \mathrm{g} \mathrm{kg}^{-1}$ for YTX. For $\mathrm{SPX} 1,400 \mu \mathrm{g} \mathrm{kg}^{-1}$ was chosen as the target level as no legislation has been established yet for this compound. The method was validated for determination in crude methanolic shellfish extracts and for extracts purified by solidphase extraction (SPE). Extracts were also subjected to hydrolysis conditions to determine the performance of the method for OA and dinophysistoxin esters. The toxins were quantified against a set of matrix-matched standards instead of standard solutions in methanol. To save valuable standard, methanolic extract instead of the homogenate was spiked with the toxin standard. This was justified by the fact that the extraction efficiency is high for all relevant
\end{abstract}

Electronic supplementary material The online version of this article (doi:10.1007/s00216-010-3886-2) contains supplementary material, which is available to authorized users.

A. Gerssen $(\varangle) \cdot$ E. H. W. van Olst • P. P. J. Mulder RIKILT - Institute of Food Safety - Wageningen UR, Akkermaalsbos 2,

6708 WB Wageningen, The Netherlands

e-mail: arjen.gerssen@wur.nl

J. de Boer

Institute for Environmental Studies, VU University,

De Boelelaan 1087,

1081 HV Amsterdam, The Netherlands toxins (above 90\%). The method performed very well with respect to accuracy, intraday precision (repeatability), interday precision (within-laboratory reproducibility), linearity, decision limit, specificity and ruggedness. At the permitted level the accuracy ranged from 102 to $111 \%$, the repeatability from 2.6 to $6.7 \%$ and the reproducibility from 4.7 to $14.2 \%$ in crude methanolic extracts. The crude extracts performed less satisfactorily with respect to the linearity (less than 0.990) and the change in LC-MS/MS sensitivity during the series (more than 25\%). SPE purification resulted in greatly improved linearity and signal stability during the series. Recently the European Food Safety Authority (EFSA) has suggested that to not exceed the acute reference dose the levels should be below $45 \mu \mathrm{g} \mathrm{kg}^{-1} \mathrm{OA}$ equivalents and $30 \mu \mathrm{g} \mathrm{kg}^{-1} \mathrm{AZA} 1$ equivalents. A single-day validation was successfully conducted at these levels. If the regulatory levels are lowered towards the EFSA suggested values, the official methods prescribed in legislation (mouse and rat bioassay) will no longer be sensitive enough. The validated LC-MS/MS method presented has the potential to replace these animal tests.

Keywords Lipophilic marine toxins $\cdot$ Liquid chromatography tandem mass spectrometry.

Method validation $\cdot$ Marine biotoxins

$\begin{array}{ll}\text { Abbreviations } \\ \text { AZA } & \text { azaspiracid } \\ \text { CC }_{\alpha} & \text { decision limit } \\ \text { CE } & \text { collision energy } \\ \text { CRM } & \text { certified reference material } \\ \text { CV } & \text { cone voltage } \\ \text { DTX } & \text { dinophysistoxin } \\ \text { EFSA } & \text { European Food Safety Authority }\end{array}$




$\begin{array}{ll}\text { ESI } & \text { electrospray ionization } \\ \text { EU } & \text { European Union } \\ \text { HPLC } & \text { high-performance liquid chromatography } \\ \text { LC } & \text { liquid chromatography } \\ \text { MMS } & \text { matrix-matched standard } \\ \text { MS } & \text { mass spectrometry } \\ \text { MS/MS } & \text { tandem mass spectrometry } \\ \text { OA } & \text { okadaic acid } \\ \text { PTX } & \text { pectenotoxin } \\ \text { SPE } & \text { solid-phase extraction } \\ \text { SPX } & \text { spirolide } \\ \text { SPX1 } & \text { 13-desmethyl spirolide-C } \\ \text { RSD } & \text { intraday repeatability } \\ \text { RSD }_{\mathrm{R}} & \text { within-laboratory reproducibility } \\ \text { YTX } & \text { yessotoxin }\end{array}$

\section{Introduction}

Filter-feeding shellfish species such as mussels, oysters and clams can be contaminated with various types of lipophilic marine toxins. These lipophilic marine toxins are produced by specific phytoplankton species such as Dinophysis acuta, Protoceratium reticulatum and Alexandrium ostenfeldii [1-4]. Consumption of shellfish contaminated with lipophilic marine toxins can cause severe intoxications $[5,6]$. The lipophilic marine toxin group comprises okadaic acid (OA), dinophysistoxins (DTXs), yessotoxins (YTXs), azaspiracids (AZAs), pectenotoxins (PTXs) and spirolides (SPXs). Of these toxins OA, DTXs and AZAs are known to cause gastrointestinal disorders in humans [7, 8]. For the other toxins (YTXs, PTXs, SPXs) no cases of intoxication in humans have been reported yet, but these toxins have been found to be lethal or at least highly toxic to mice when injected intraperitoneally [9-11]. Legislation and routine monitoring programmes have been established to protect the consumer [12]. The permitted levels in whole-flesh shellfish have been set for the sum of all relevant OA, DTXs and PTXs at $160 \mu \mathrm{g} \mathrm{kg}^{-1}$, for the sum of relevant YTXs at $1,000 \mu \mathrm{g} \mathrm{kg}^{-1}$ and for the sum of the relevant AZAs at $160 \mu \mathrm{g} \mathrm{kg}^{-1}$ [12]. For SPXs no legislation has been established yet. When the current legislation was established, toxicity data on most toxins were scarce or even lacking. More data have become available since, and recently the European Food Safety Authority (EFSA) published several opinions in which this new toxicological information is evaluated. From the EFSA documents it can be seen that the current permitted levels for OA, DTXs, PTXs and AZAs may not be sufficient to exclude the risk of intoxication [13-15], whereas for YTXs the permitted level overestimates the toxicity [16]. The EFSA has proposed the following protection levels: the sum of OA and DTXs at $45 \mu \mathrm{g} \mathrm{kg}^{-1}$, for AZAs $30 \mu \mathrm{g} \mathrm{kg}^{-1}$, for PTXs $120 \mu \mathrm{g} \mathrm{kg}^{-1}$ and for YTXs $3,750 \mu \mathrm{g} \mathrm{kg}^{-1}$ [13-16]. It may be expected that the EFSA opinions will initiate a discussion among the different member states of the European Union (EU) on whether or not the current permitted levels in the EU legislation should be changed. Lowering of permitted levels may have a serious impact on the shellfish industry. It will also have an impact on the methods that can be applied to monitor legislation compliance. It is highly unlikely that the official reference methods currently prescribed in legislation, the rat bioassay and the mouse bioassay, can be adapted to the proposed levels [17]. These assays are under discussion anyway because of ethical questions. For many years, EU legislation has prescribed the need for a reduction, refinement and replacement of animal experiments [18]; therefore, there is urgent need for alternative methods that are sensitive enough for all relevant toxins. Alternative methods such as biochemical or chemical methods are promising methods to replace the current animal tests. Alternative biochemical methods, such as a protein phosphatase $2 \mathrm{~A}$ inhibition assay and an enzyme-linked immunosorbent assay, have been developed for OA (including DTXs) and for YTXs, respectively $[19,20]$. These methods all focus on a specific lipophilic marine toxin group. Alternative chemical methods that cover all lipophilic marine toxin classes are based on liquid chromatography (LC) coupled with (tandem) mass spectrometry $[\mathrm{MS}(/ \mathrm{MS})]$. Some of these LC-MS-based multitoxin methods can be used for routine monitoring purposes [21-24]. One of the drawbacks of LC-MS/MS methods is their sensitivity to matrix effects. Matrix effects can lead to an under- or overestimation of the concentration present in shellfish. To remove or reduce these matrix effects, several clean-up methods have been developed $[25,26]$. In this paper we present the results of an in-house validation study of our recently published LC-MS/MS method [24]. The effect of solid-phase extraction (SPE) for sample clean up was also studied and included in the validation.

\section{Materials and methods}

Chemicals and standards

Water was deionized and passed through a Milli-Q water purification system (Millipore, Billerica, MA, USA). Acetonitrile [high-performance LC (HPLC) supra gradient] and methanol (absolute, HPLC grade) were purchased from Biosolve (Valkenswaard, The Netherlands). Ammonium hydroxide (25\%) and hydrochloric acid (37\%) were purchased from VWR International (Amsterdam, The Netherlands). Sodium hydroxide was purchased from 
Merck (Darmstadt, Germany). The certified reference materials (CRMs) OA (CRM-OA-b $24.1 \pm 0.8 \mu \mathrm{g} \mathrm{mL}{ }^{-1}$ ), YTX (CRM-YTX $5.3 \pm 0.3 \mu \mathrm{g} \mathrm{mL}^{-1}$ ), AZA1 (CRM-AZA1 $1.24 \pm 0.07 \mu \mathrm{g} \mathrm{mL}^{-1}$ ), PTX2 (CRM-PTX2 $8.6 \pm 0.3 \mu \mathrm{g} \mathrm{mL}^{-1}$ ) and 13-desmethyl spirolide-C (SPX1) (CRM-SPX1 7.0 \pm $0.4 \mu \mathrm{g} \mathrm{mL}^{-1}$ ) and MusB (CRM-mus-b $10.1 \mu \mathrm{g} \mathrm{g}^{-1} \mathrm{OA}$ ) were purchased from the National Research Council, Institute for Marine Biosciences (Halifax, Canada).

Preparation of extracts

Homogenates of blank mussels (Mytilus edulis), oysters (Crassosrea gigas), cockles (Cerastoderma edule) and clams (Ensis directus) were prepared by homogenizing $100 \mathrm{~g}$ of whole-flesh tissue with a T25 Ultra Turrax mixer at 24,000 rpm (IKA ${ }^{\circledR}$ Works, Wilmington, NC, USA). One gram of shellfish homogenate was extracted in triplicate with $3 \mathrm{~mL}$ methanol. After each addition of methanol, the extract was vortex-mixed for $1 \mathrm{~min}$. After the vortexmixing, the extract was centrifuged for $5 \mathrm{~min}$ at $2,000 \mathrm{~g}$. The supernatant was transferred to a $10-\mathrm{mL}$ volumetric flask and after the third extraction the volume was made up to $10 \mathrm{~mL}$ with methanol. The crude shellfish extract was filtered through a HT tuffryn $0.2-\mu \mathrm{m}$ membrane filter (Pall, East Hills, NY, USA) prior to spiking.

\section{Determination of extraction efficiency}

To determine the extraction efficiency, samples naturally contaminated with OA, DTX2 and DTX3 and a sample contaminated with OA, DTX2, AZA1, AZA2 and AZA3 were extracted in duplicate. The homogenate $(1 \mathrm{~g})$ was extracted four times with $3 \mathrm{~mL}$ methanol. After each extraction the supernatant was transferred to a $10-\mathrm{mL}$ volumetric flask and volume was made up to $10 \mathrm{~mL}$ with methanol. After the four methanol extractions a fifth extraction was performed with $3 \mathrm{~mL}$ acetone. The acetone extract was evaporated to dryness and reconstituted in methanol. From each extraction step the relative amount of toxin transferred was calculated. Furthermore, for the extraction efficiency six CRM MusB samples containing $10.1 \mu \mathrm{g} \mathrm{g}^{-1} \mathrm{OA}$ and six blank shellfish samples spiked at 0.5 times the permitted level with YTX, AZA1, PTX2 and SPX1 were extracted is the same way as described in "Preparation of extracts".

Preparation of matrix-matched standards

A mixed standard stock solution containing $320 \mathrm{ng} \mathrm{mL}^{-1}$ OA, AZA1 and PTX2, 2,000 $\mathrm{ng} \mathrm{mL^{-1 }}$ YTX and $800 \mathrm{ng} \mathrm{mL}^{-1}$ SPX1 was prepared in methanol. Matrixmatched standards (MMS) were used to construct a calibration curve. Blank extracts $(1.8 \mathrm{~mL})$ were spiked with, respectively, $0,25,50,100$ and $150 \mu \mathrm{L}$ mixed stock solution, representing $0,0.25,0.5,1$ and 1.5 times the permitted level (Table 1). For SPX1 no permitted level has been established yet. Therefore, in this study a concentration of $400 \mu \mathrm{g} \mathrm{kg}^{-1}$ was chosen as the target level. The total volume of each extract was adjusted to $2 \mathrm{~mL}$ with methanol.

\section{SPE clean-up}

The SPE procedure was carried out as described by Gerssen et al. [25]. Strata-X cartridges, $30 \mathrm{mg}, 1 \mathrm{~mL}$ (Phenomenex, Torrance, CA, USA), were conditioned and equilibrated using $1 \mathrm{~mL}$ of methanol and methanol/water $(30: 70, \mathrm{v} / \mathrm{v})$, respectively. The methanolic shellfish extracts $(1.2 \mathrm{~mL})$ were diluted with $2.8 \mathrm{~mL}$ water. After $4 \mathrm{~mL}$ of diluted extract had been loaded on the cartridge, the cartridge was washed with $1 \mathrm{~mL}$ methanol/water $(20: 80, \mathrm{v} / \mathrm{v})$. Finally, the toxins were eluted from the cartridge with $1.2 \mathrm{~mL}$ methanol containing $0.3 \% \mathrm{v} / \mathrm{v}$ of a $25 \%$ ammonium hydroxide solution in water.

Preparation of extracts for determination of the performance characteristics

Blank mussel and oyster extracts, different from the ones used for the MMS, were spiked. The extract $(1.8 \mathrm{~mL})$ was spiked with 50,100 and $150 \mu \mathrm{L}(0.5,1,1.5$ times the permitted level, respectively) of the mixed standard stock solution. The total volume was made up to $2 \mathrm{~mL}$ by adding 150,100 and $50 \mu \mathrm{L}$ methanol, respectively. After the spiking, an aliquot $(1.2 \mathrm{~mL})$ of the extract was purified by SPE before analysis. The remainder of the extract was analysed without further cleanup. On a separate occasion, eight different shellfish extracts (two mussels, two oysters, two cockles, two clams) were prepared and spiked at 0.5 times the permitted level to determine the interspecies repeatability.

\section{Hydrolysis}

To determine the amount of esters of OA, DTX1 and DTX2 present in the shellfish sample, alkaline hydrolysis can be

Table 1 Current permitted levels in EU legislation and levels proposed by EFSA

\begin{tabular}{lll}
\hline Toxin & Legislation $\left(\mu \mathrm{g} \mathrm{kg}^{-1}\right)$ & EFSA opinion $\left(\mu \mathrm{g} \mathrm{kg}^{-1}\right)$ \\
\hline OA and DTXs & $160^{\mathrm{a}}$ & 45 \\
PTXs & & 120 \\
YTXs & 1000 & 3750 \\
AZAs & 160 & 32 \\
\hline
\end{tabular}

a including PTXs 
performed [27]. However, as no esterified standards of OA and DTX were available, the performance of the method was tested by subjecting OA to alkaline hydrolysis conditions. For the validation of hydrolysis an MMS as well as spiked extracts containing OA were prepared at 0 , $0.25,0.5,1$ and 1.5 times the current permitted level (Table 1). In a test tube, $250 \mu \mathrm{L}$ of $2.5 \mathrm{M}$ sodium hydroxide solution was added to $2 \mathrm{~mL}$ spiked extract. The contents of the closed tube were mixed and the tube was placed in a water bath at $76^{\circ} \mathrm{C}$. After $45 \mathrm{~min}$ the hydrolysed extract was cooled to room temperature and neutralized with 250 $\mu \mathrm{L}$ of $2.5 \mathrm{M}$ hydrochloric acid. To check for evaporation of methanol during heating of the test tubes, they were weighed before and after hydrolysis $(n=20)$. An 1.2-mL aliquot was purified by SPE before analysis; the remainder was analysed without further purification.

\section{LC-MS/MS analysis}

Chromatographic separation was achieved using a Shimadzu HPLC system (Shimadzu, 's-Hertogenbosch, The Netherlands) consisting of a degasser (DGU-20A ${ }^{3}$ ), a binary pump system (LC20-AD), an autosampler (SIL-HTc) and a column oven (CTO-20A). Separation was achieved on a Waters X-Bridge ${ }^{\mathrm{TM}} \mathrm{C}_{18}(150 \mathrm{~mm} \times$ $3 \mathrm{~mm}, 5 \mu \mathrm{m})$ column. Mobile phase A was water and mobile phase B was acetonitrile/water $(90: 10, \mathrm{v} / \mathrm{v})$, both containing $6.7 \mathrm{mM}$ ammonium hydroxide ( $\mathrm{pH} 11)$. A flow rate of $0.4 \mathrm{~mL} \mathrm{~min}^{-1}$ was used. The gradient started at $10 \%$ phase B. This composition was kept for $1 \mathrm{~min}$ and was then changed linearly in 9 min to $90 \%$ phase B. The mobile phase composition was kept at $90 \%$ phase B for 3 min and returned to $10 \%$ phase $\mathrm{B}$ in $2 \mathrm{~min}$. An equilibration time of 4 min was allowed before the next injection. An injection volume of $10 \mu \mathrm{L}$ was used and the column temperature was kept at $40^{\circ} \mathrm{C}$. Mass-spectrometric detection was performed using a Mircromass Quattro Ultima tandem mass spectrometer (Waters-Micromass, Manchester, UK) equipped with an electrospray ionization (ESI) interface. The mass spectrometer was operated in both negative and positive ESI mode. In both modes a capillary voltage of $2.8 \mathrm{kV}$, a desolvation gas temperature of $350^{\circ} \mathrm{C}$ at a $\mathrm{N}_{2}$ flow rate of $600 \mathrm{Lh}^{-1}$, a source temperature of $120^{\circ} \mathrm{C}$ and a nebulizer gas $\left(\mathrm{N}_{2}\right)$ flow rate of $100 \mathrm{Lh}^{-1}$ were used. Argon was used as a collision-induceddissociation gas at a pressure of $2.5 \times 10^{-3} \mathrm{mbar}$. The cone voltage $(\mathrm{CV})$ and the collision energy $(\mathrm{CE})$ were optimized for each toxin. Two product ions were selected for each toxin, to allow quantification as well as identification of the specific toxin: OA $803.5 \rightarrow 255.2$ (CV $60 \mathrm{~V}, \mathrm{CE} 45 \mathrm{eV}$ ), OA 803.5 $\rightarrow 113.1(\mathrm{CV} 60 \mathrm{~V}, \mathrm{CE} 50 \mathrm{eV})$, YTX $570.4 \rightarrow 467.4(\mathrm{CV}$ $75 \mathrm{~V}$, CE $30 \mathrm{eV})$, YTX $570.4 \rightarrow 396.4(\mathrm{CV} 75 \mathrm{~V}, \mathrm{CE}$ $30 \mathrm{eV}$ ), AZA1 $842.5 \rightarrow 824.5(\mathrm{CV} 35 \mathrm{~V}$, CE $30 \mathrm{eV})$, AZA1 $842.5 \rightarrow 672.4(\mathrm{CV} 35 \mathrm{~V}, \mathrm{CE} 40 \mathrm{eV})$, PTX2 $876.5 \rightarrow 823.5$
$(\mathrm{CV} 40 \mathrm{~V}, \mathrm{CE} 30 \mathrm{eV})$, PTX2 $876.5 \rightarrow 213.1(\mathrm{CV} 40 \mathrm{~V}, \mathrm{CE}$ $30 \mathrm{eV})$, SPX1 $692.5 \rightarrow 444.2(\mathrm{CV} 40 \mathrm{~V}, \mathrm{CE}: 40 \mathrm{eV})$ and SPX1 $692.5 \rightarrow 164.3(\mathrm{CV} 40 \mathrm{~V}, \mathrm{CE} 50 \mathrm{eV})$.

\section{Validation parameters investigated}

The method was validated using EU Commission Decision $2002 / 657 / \mathrm{EC}$ as a guideline. Seven replicates, at each of the three spiking levels $(0.5,1$ and 1.5 times the permitted level), were analysed. Analysis was carried out on three separate occasions using two different types of blank shellfish extract (day 1 oyster, day 2 mussel and day 3 mussel). The accuracy, intraday precision (intraday repeatability, $\mathrm{RSD}_{\mathrm{r}}$ ), interday precision (within-laboratory reproducibility, $\mathrm{RSD}_{\mathrm{R}}$ ), linearity, decision limit $\left(\mathrm{CC}_{\alpha}\right)$, specificity and ruggedness were determined.

\section{Results and discussion}

EU legislation demands that the validation of an alternative method for marine toxins should be carried out according to an internationally recognized protocol [28]. Commission Decision 2002/657/EC describes the performance characteristics of analytical methods for so-called group A and group B substances in products of animal origin [29]. As mentioned in Council Directive 1996/23/EC, group B substances comprise compounds such as veterinary drugs, environmental contaminants and mycotoxins [30]. Therefore, we decided to use Commission Decision 2002/657/EC as the basis for the validation of the analytical method for lipophilic marine toxins.

\section{Extraction efficiency}

In former validation studies an important aspect was the use of methanolic solutions of toxins for the construction of calibration curves $[22,23]$. We have recently shown that significant matrix effects can be observed in shellfish extracts and that one of the ways to compensate for these effects is to use MMS [25]. To save valuable toxin standards, it is preferred to add toxin standards to methanolic extracts rather than to the shellfish homogenate itself. Spiking of extracts is justified when the extraction efficiency is very high (above 90\%) for all relevant toxins. To determine the extraction efficiency, two naturally contaminated shellfish samples were extracted with methanol (4 times) and acetone (once). As can be seen in Fig. 1, after three methanol extractions more than $90 \%$ of the toxin content was extracted. Even the more lipophilic OA and DTX esters were extracted with over $90 \%$ efficiency. Furthermore, when the MusB CRM was subjected to the normal procedure of three extractions with $3 \mathrm{~mL}$ methanol, the recovery of OA 

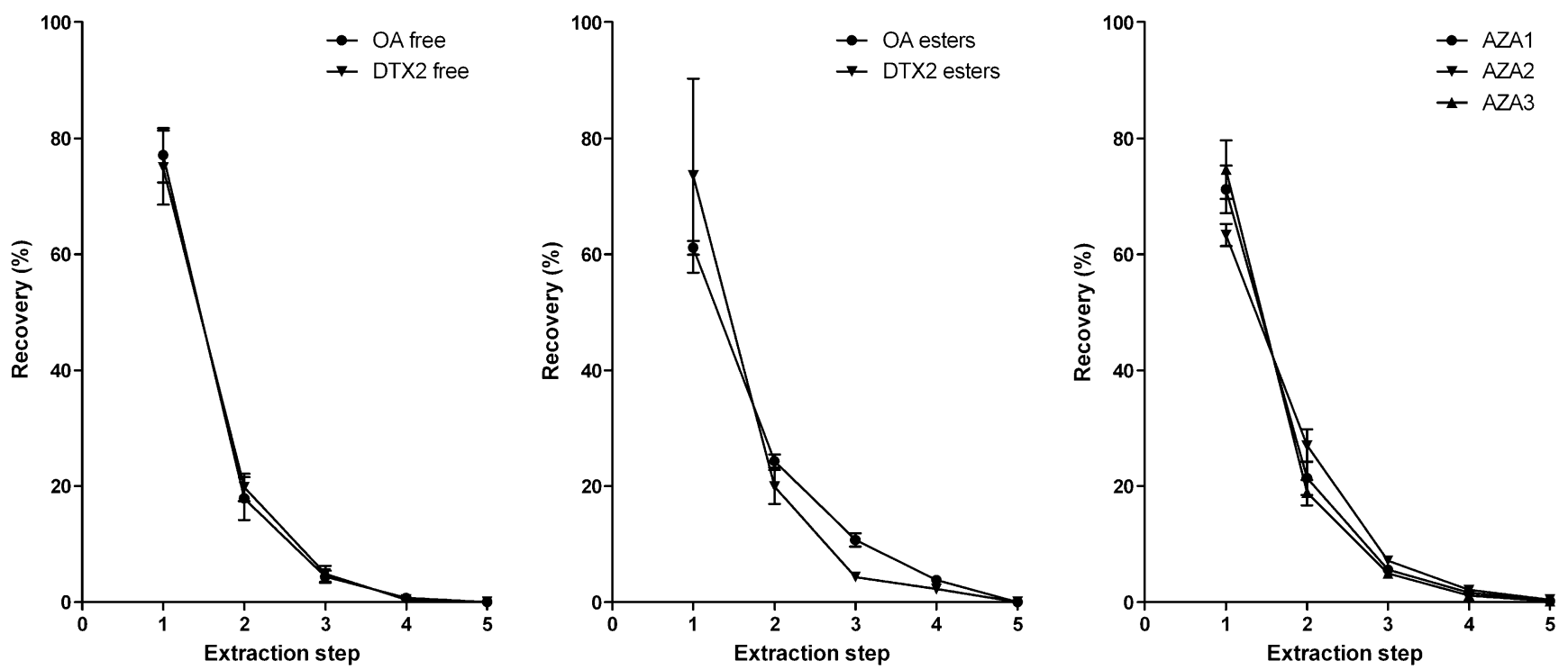

Fig. 1 Repeated extraction from shellfish to investigate the toxin extraction efficiency. Methanol was used for the first four extractions, and acetone for the final extraction. $O A$ okadaic acid, DTX dinophysistoxin, $A Z A$ azaspiracid

was $97.2 \pm 5.1 \%(n=6)$. Extraction of six different matrices [mussel, cockle, clam and oyster $(n=6)]$ spiked with YTX, AZA1, PTX2 and SPX1 at 0.5 times the permitted level resulted in average recoveries of 93.5, 97.0, 93.2 and $96.9 \%$, respectively. Therefore, it is very unlikely that spiking of extracts will lead to false negatives. In the validation study extracts were analysed with and without SPE purification to determine the effect of an additional clean-up step on the performance parameters of the method.

\section{Accuracy}

The accuracy of the method in terms of recovery was determined instead of the trueness, because no CRMs at the regulatory limit are available. The accuracy was determined by comparing the amount of toxin used to spike the extract with the amount of toxin found. Commission Decision 2002/ 657/EC points out that the accuracy of a method with analyte levels above $10 \mu \mathrm{g} \mathrm{kg}^{-1}$ should be between 80 and $110 \%$. Overall, good accuracies were obtained (Table 2); only in a few instances were slightly elevated accuracies obtained. The lowest accuracy obtained was $94 \%$ for YTX spiked at 1.5 times the permitted level and analysed after SPE clean-up. The highest accuracy found was $119 \%$ for PTX2 spiked at 1.5 times the permitted level in the crude extract. Consequently, with respect to accuracy it was concluded that SPE clean-up resulted in only a modest improvement.

\section{Intraday repeatability}

The $\mathrm{RSD}_{\mathrm{r}}$ of the crude extracts as well as that of the cleaned extracts was good (Table 2). The repeatability for the samples analysed without SPE clean-up varied between $2.5 \%$ for AZA1 spiked at the permitted level and YTX spiked at 1.5 times the permitted level and $12.0 \%$ for PTX2 spiked at 0.5 times the permitted level. For samples analysed after SPE, the $\mathrm{RSD}_{\mathrm{r}}$ varied between 3.3\% for YTX spiked at 1.5 times the permitted level and $10.7 \%$ for SPX1 spiked at the permitted level. Overall, the repeatability for most of the toxins in the crude extracts was somewhat better than that of the SPEcleaned extracts. For the hydrolysed extracts containing OA, the repeatability was somewhat better when SPE clean-up was applied. To check if the higher $\mathrm{RSD}_{\mathrm{r}}$ of the crude hydrolysed extracts was caused by evaporation of the methanol during heating, the weight of the test tubes before and after hydrolysis was recorded. The loss in weight was $0.14 \pm 0.08 \%(n=20)$, which is negligible. It was anticipated that purification of the extracts would result in improved repeatability; however, this was not found. One possible explanation is that SPE clean-up introduces an extra error (variation in recovery of the SPE) in the results. This recovery error would more or less counterbalance the positive effect of the SPE on the system performance, which will be discussed in "Linearity".

To investigate whether interspecies differences between the various shellfish matrices play a role, eight different shellfish extracts (two mussels, two oysters, two cockles and two clams), originating from different regions and sampled on two different occasions (March and June 2009), were analysed after being spiking at 0.5 times the permitted level (Table 3). These shellfish extracts were quantified against an MMS calibration curve prepared from an unrelated blank mussel extract. The repeatability obtained was good, with an average $\mathrm{RSD}_{\mathrm{r}}$ of $5.4 \%$ for the crude extracts and $5.1 \%$ for the SPE- 
Table 2 Multiple day validation results for the analysis of lipophilic marine biotoxins in shellfish (mussel and oyster) ( $\mathrm{n}=21)$

\begin{tabular}{|c|c|c|c|c|c|c|c|}
\hline & & Fortification level $\mu \mathrm{g} \mathrm{kg}^{-1}$ & Accuracy \% & $\mathrm{RSD}_{\mathrm{r}} \%$ & $\mathrm{RSD}_{\mathrm{R}} \%$ & $\mathrm{CC}_{\alpha}^{\mathrm{a}} \mu \mathrm{g} \mathrm{kg}^{-1}$ & $\mathrm{R}^{\mathrm{b}}$ \\
\hline \multirow[t]{12}{*}{$\mathrm{OA}$} & \multirow[t]{3}{*}{ Without SPE } & 80 & 103 & 7.2 & 10.1 & \multirow[t]{3}{*}{194} & \multirow[t]{3}{*}{$0.997-1.000$} \\
\hline & & 160 & 103 & 4.6 & 12.4 & & \\
\hline & & 240 & 101 & 3.7 & 15.6 & & \\
\hline & \multirow[t]{3}{*}{ With SPE } & 80 & 111 & 7.4 & 8.5 & \multirow[t]{3}{*}{184} & \multirow[t]{3}{*}{$0.995-0.999$} \\
\hline & & 160 & 98 & 7.2 & 9.1 & & \\
\hline & & 240 & 96 & 6.3 & 7.5 & & \\
\hline & \multirow[t]{3}{*}{ Hydrolysis, without SPE } & 80 & 99 & 8.4 & 9.0 & \multirow[t]{3}{*}{200} & \multirow[t]{3}{*}{$0.993-0.998$} \\
\hline & & 160 & 106 & 6.7 & 14.2 & & \\
\hline & & 240 & 106 & 4.8 & 11.0 & & \\
\hline & \multirow[t]{3}{*}{ Hydrolysis, with SPE } & 80 & 103 & 4.6 & 4.9 & \multirow[t]{3}{*}{176} & \multirow[t]{3}{*}{$0.992-1.000$} \\
\hline & & 160 & 100 & 5.9 & 6.1 & & \\
\hline & & 240 & 98 & 3.7 & 6.6 & & \\
\hline \multirow[t]{6}{*}{ YTX } & \multirow[t]{3}{*}{ Without SPE } & 500 & 100 & 3.7 & 7.2 & \multirow[t]{3}{*}{1175} & \multirow[t]{3}{*}{$0.998-1.000$} \\
\hline & & 1000 & 102 & 2.8 & 10.4 & & \\
\hline & & 1500 & 102 & 2.5 & 12.0 & & \\
\hline & \multirow[t]{3}{*}{ With SPE } & 500 & 106 & 4.5 & 4.6 & \multirow[t]{3}{*}{1106} & \multirow[t]{3}{*}{$0.999-1.000$} \\
\hline & & 1000 & 98 & 4.8 & 6.6 & & \\
\hline & & 1500 & 94 & 3.3 & 3.8 & & \\
\hline \multirow[t]{6}{*}{ AZA1 } & \multirow[t]{3}{*}{ Without SPE } & 80 & 102 & 5.4 & 7.0 & \multirow[t]{3}{*}{173} & \multirow[t]{3}{*}{$0.995-1.000$} \\
\hline & & 160 & 110 & 2.5 & 4.7 & & \\
\hline & & 240 & 113 & 2.9 & 7.3 & & \\
\hline & \multirow[t]{3}{*}{ With SPE } & 80 & 102 & 3.5 & 3.6 & \multirow[t]{3}{*}{182} & \multirow[t]{3}{*}{$0.999-1.000$} \\
\hline & & 160 & 100 & 7.6 & 8.5 & & \\
\hline & & 240 & 99 & 4.0 & 4.6 & & \\
\hline PTX2 & Without SPE & 80 & 95 & 12.0 & 17.5 & 176 & $0.996-1.000$ \\
\hline & & 160 & 111 & 5.4 & 5.6 & & \\
\hline & & 240 & 119 & 3.6 & 3.7 & & \\
\hline & With SPE & 80 & 103 & 6.8 & 7.4 & 182 & $0.999-1.000$ \\
\hline & & 160 & 104 & 7.6 & 8.3 & & \\
\hline & & 240 & 104 & 6.0 & 7.0 & & \\
\hline SPX1 & Without SPE & 200 & 106 & 4.3 & 6.0 & 460 & $0.999-1.000$ \\
\hline & & 400 & 108 & 2.7 & 8.5 & & \\
\hline & & 600 & 109 & 2.5 & 11.8 & & \\
\hline & With SPE & 200 & 106 & 7.1 & 7.3 & 469 & $0.996-1.000$ \\
\hline & & 400 & 97 & 10.7 & 10.8 & & \\
\hline & & 600 & 96 & 6.7 & 7.8 & & \\
\hline
\end{tabular}

a at $95 \%$ confidence interval.

b Minimum- maximum correlation obtained from the MMS series analysed before and after the sample extracts.

cleaned extracts. The poorest repeatability among the species was found for $\mathrm{OA}$ in the crude extract $\left(\mathrm{RSD}_{\mathrm{r}}\right.$ of $\left.6.9 \%\right)$ and for $\mathrm{OA}$ in the cleaned extract $\left(\mathrm{RSD}_{\mathrm{r}}\right.$ of $\left.6.5 \%\right)$. This experiment shows that effects of interspecies and interseason differences are relatively small. This also means that a set of MMS prepared in a particular shellfish extract can be used without problems for other shellfish matrices.

\section{Within-laboratory reproducibility}

The $\mathrm{RSD}_{\mathrm{R}}$ was good for all toxins analysed (Table 2). The highest $\mathrm{RSD}_{\mathrm{R}}$ was obtained for PTX2 (17.6\%) analysed at
0.5 times the permitted level in crude extract. After SPE purification this improved to an $\mathrm{RSD}_{\mathrm{R}}$ of $9.9 \%$ (Table 2). The lowest $\mathrm{RSD}_{\mathrm{R}}$ was obtained for AZA1 (4.6\%) at 1.5 times the permitted level analysed after SPE clean-up. In general, the $\mathrm{RSD}_{\mathrm{R}}$ were better in the SPE-cleaned extracts, especially for OA and YTX, which were recorded in negative ESI mode.

The $\mathrm{RSD}_{\mathrm{R}}$ can also be expressed as HorRat values [31], which can be calculated using the following equation:

$$
\text { HorRat }_{R}=R S D_{R}(\text { obtained }) / R S D_{R}(\text { calculated })
$$

in which $\mathrm{RSD}_{\mathrm{R}}$ (obtained) is the relative standard deviation of the measured reproducibility and $\mathrm{RSD}_{\mathrm{R}}$ (calculated) is the 
Table 3 Accuracy and repeatability of crude extracts of various shellfish species spiked at 0.5 PL ( $\mathrm{n}=1$ )

\begin{tabular}{|c|c|c|c|c|c|c|}
\hline \multirow[t]{2}{*}{ Sampled } & \multirow[t]{2}{*}{ Sample } & \multicolumn{5}{|c|}{ Average concentration found } \\
\hline & & $\mathrm{OA}\left(\mu \mathrm{g} \mathrm{kg}^{-1}\right)$ & YTX $\left(\mu \mathrm{g} \mathrm{kg}^{-1}\right)$ & AZA1 $\left(\mu \mathrm{g} \mathrm{kg}^{-1}\right)$ & PTX2 $\left(\mu \mathrm{g} \mathrm{kg}^{-1}\right)$ & $\operatorname{SPX} 1\left(\mu \mathrm{g} \mathrm{kg}^{-1}\right)$ \\
\hline \multirow[t]{4}{*}{ March } & Mussel & 84.1 & 523.5 & 80.8 & 78.0 & 218.5 \\
\hline & Oysters & 79.7 & 512.9 & 77.1 & 76.2 & 204.7 \\
\hline & Ensis & 83.8 & 498.6 & 73.6 & 82.3 & 208.1 \\
\hline & Cockle & 91.2 & 527.1 & 82.8 & 84.6 & 203.9 \\
\hline \multirow[t]{6}{*}{ June } & Mussel & 92.9 & 517.9 & 78.3 & 85.5 & 237.9 \\
\hline & Oysters & 95.4 & 501.8 & 82.0 & 82.4 & 196.0 \\
\hline & Ensis & 84.2 & 518.6 & 83.2 & 75.5 & 204.4 \\
\hline & Cockle & 79.9 & 521.9 & 72.8 & 72.7 & 193.3 \\
\hline & $\mathrm{RSD}_{\mathrm{r}}(\%)$ & 6.9 & 2.0 & 5.2 & 5.9 & 6.8 \\
\hline & Accuracy $(\%)$ & 108.0 & 103.1 & 98.5 & 99.6 & 104.2 \\
\hline
\end{tabular}

relative standard deviation of the precision calculated by the Horwitz equation [31]:

$R S D_{R}=2^{(1-0.5 \log C)}$

in which $C$ is the concentration of the toxin expressed in grams per gram of sample. The $\mathrm{RSD}_{\mathrm{R}}$ is considered as acceptable when the HorRat value is less than 2; below 1.5 it is considered as good and below 1 as excellent. It can be concluded that the $\mathrm{RSD}_{\mathrm{R}}$ was excellent for all extracts analysed (Fig. S1). The highest HorRat value was obtained for PTX2 (17.6\%, HorRat of 0.8$)$ analysed at 0.5 times the permitted level in the crude extract. As already mentioned, the $\mathrm{RSD}_{\mathrm{R}}$ is, on average, slightly better for the extracts cleaned by SPE (average HorRat of $0.4 \pm 0.1$ ) than for the crude extracts (average HorRat of $0.5 \pm 0.2$ ).

Linearity

A MMS calibration was run at the beginning and at the end of each series and the linearity of both curves was calculated by the least-squares method. Linearity was considered acceptable when the correlation was at least 0.990. For all MMS series analysed in the crude and purified extracts the correlation was good (0.992 or higher; Table 2). No internal standards are available that can be used to correct for changes in sensitivity during analysis. Therefore, a more or less constant sensitivity during the analytical series is very important. This was checked by combining the MMS series before and after the sample extracts into one calibration curve. The correlation coefficient of this calibration curve should be 0.990 or better. This was the case for the samples which were purified by SPE. For these series combined calibration curves could be constructed with correlations of 0.990 or higher for all toxins analysed, indicating that a loss or change in sensitivity during the series is not a serious problem (maximum 22\% for YTX). In contrast, in the crude extracts all toxins except YTX (21\%) suffered from a drift in sensitivity by more than $25 \%$ (maximum 137.2\% for PTX2), resulting in combined calibration curves with a correlation of less than 0.990 ( 0.854 for PTX2). It is clear that the stability of the LC-MS/MS system remained more constant over a longer period of time when cleaned extracts were injected. This is especially important when long series have to be run. Alternatively, the series can be kept short, or a control sample should be included that is analysed at regular intervals during the series.

\section{Decision limit}

Twenty samples were fortified with the various toxins at the permitted levels and analysed. For these samples the standard deviation of the $\mathrm{RSD}_{\mathrm{R}}$ was calculated. $\mathrm{CC} \alpha$ can be determined using the equation:

$C C \alpha=P L+t \times S D_{R}$

in which PL is the permitted level for the toxins in micrograms per kilogram, $t$ is 1.64 from a one-tailed $t$ distribution with $P=$ 0.05 (with an infinite number degrees of freedom), and $\mathrm{SD}_{\mathrm{R}}$ is the standard deviation of the $\mathrm{RSD}_{\mathrm{R}}$. If the concentration of a toxin in a sample is found at or above the $\mathrm{CC} \alpha$, it can be concluded with a probability of $1-\alpha$ or $95 \%(\alpha=5 \%)$ that the sample is above the permitted level and thus non-compliant. No significant differences were obtained for the $\mathrm{CC} \alpha$ between the crude extracts and the SPE-purified extracts, except for YTX and hydrolysed OA. For these toxins SPE clean-up resulted in a lower $\mathrm{CC} \alpha$ (Table 2).

\section{Specificity}

Twenty-one different blank samples (seven mussels, four oysters, eight cockles, two clams) were analysed to determine if interfering peaks were present in the selected mass traces representing the different toxins. In none of the 

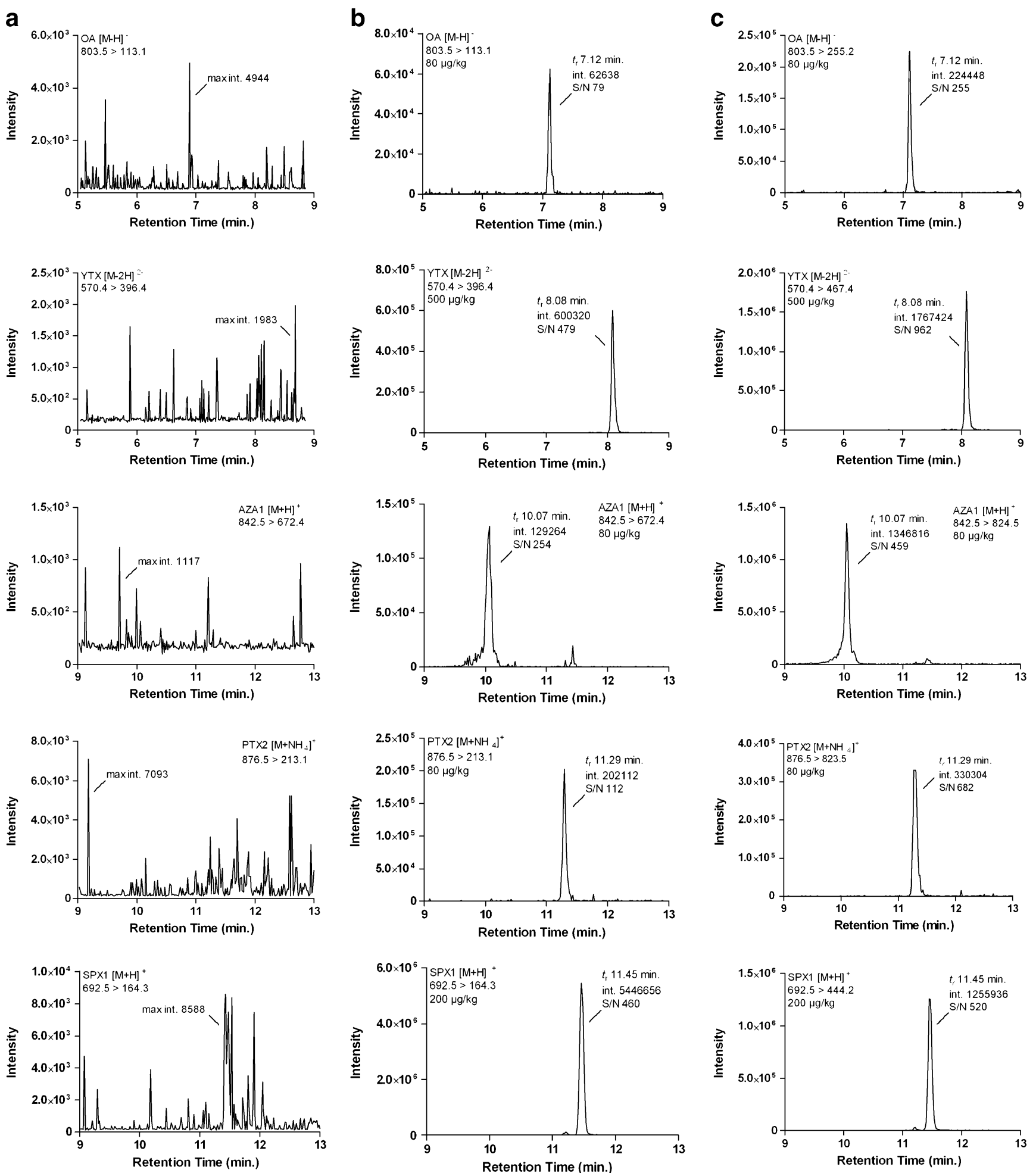

Fig. 2 Liquid chromatography tandem mas spectrometry chromatograms of selected transitions (weakest transition shown) of a a blank mussel extract, b a blank mussel extract spiked with OA, yessotoxin $(Y T X)$, AZA1, pectenotoxin-2 (PTX2) and 13-desmethyl spirolide-C
$(S P X 1)$ at 0.5 times the permitted level and $\mathbf{c}$ the strongest transition for a blank mussel spiked with OA, YTX, AZA1, PTX2 and SPX1 at 0.5 times the permitted level 
Table 4 Single-day validation results obtained for the analysis of lipophilic marine biotoxins in shellfish (mussel) at the levels proposed by the European Food Safety Authority $(n=7)^{a}$

\begin{tabular}{|c|c|c|c|c|c|c|}
\hline & & Fortification level $\mu \mathrm{g} \mathrm{kg}^{-1}$ & Accuracy \% & $\mathrm{RSD}_{\mathrm{r}} \%$ & $\mathrm{CC}_{\alpha} \mu \mathrm{g} \mathrm{kg}^{-1}$ & $\mathrm{R}^{\mathrm{b}}$ \\
\hline \multirow[t]{3}{*}{$\mathrm{OA}$} & \multirow[t]{3}{*}{ Without SPE } & 22.5 & 96 & 10.1 & \multirow[t]{3}{*}{53.3} & \multirow[t]{3}{*}{$0.998-1.000$} \\
\hline & & 45 & 113 & 6.1 & & \\
\hline & & 67.5 & 108 & 5.4 & & \\
\hline \multirow[t]{3}{*}{ AZA1 } & \multirow[t]{3}{*}{ With SPE } & 16 & 107 & 2.1 & \multirow[t]{3}{*}{34.5} & \multirow[t]{3}{*}{$0.999-1.000$} \\
\hline & & 32 & 106 & 2.7 & & \\
\hline & & 48 & 104 & 1.2 & & \\
\hline
\end{tabular}

${ }^{\mathrm{a}}$ The validation was conducted before the document for the AZAs was published. The proposed permitted level for AZA $\left(30 \mu \mathrm{g} \mathrm{kg}{ }^{-1}\right)$ slightly differs from the level chosen in this study $\left(32 \mu \mathrm{g} \mathrm{kg}^{-1}\right)$.

${ }^{\mathrm{b}}$ Minimum- maximum correlation calculated from the MMS series analyzed.

analysed samples were interfering responses detected (Fig. 2).

\section{Ruggedness}

The ruggedness of the method for small variations which can accidentally happen within a laboratory was tested. No major changes (different mass spectrometer settings etc.) were investigated. The vortex-mixing time was extended from 1 to $2 \mathrm{~min}$; the speed of the centrifuge was increased from 2,000 $g$ to 2,500 $g$ and with SPE the contents of the cartridges were eluted for an extra minute. For the ruggedness, the results obtained should be within the standard deviation of the $\mathrm{RSD}_{\mathrm{R}}$. For all toxins tested under the conditions mentioned, the method performed within this limit.

Single-day validation of OA and AZA1 at EFSA proposed levels

The EFSA has recently proposed new permitted levels for most of the lipophilic marine toxins. For OA and AZA1 the proposed safety levels are much lower $\left(45 \mu \mathrm{g} \mathrm{kg}^{-1}\right.$ for OA and $30 \mu \mathrm{g} \mathrm{kg}^{-1}$ for AZA1) than the current permitted levels. With regard to the PTXs, the proposed permitted level of $120 \mu \mathrm{g} \mathrm{kg}^{-1}$ falls within the range of the validation performed $\left(80,160,240 \mu \mathrm{g} \mathrm{kg}^{-1}\right)$. As the EFSA has suggested increasing the YTX permitted level from 1,000 to $3,750 \mu \mathrm{g} \mathrm{kg}^{-1}$, it was considered less important to determine the performance of the method at this higher concentration. To determine if the method for OA and AZA1 also performs well at the levels proposed by the EFSA, an additional single-day validation was carried out (Table 4). The performance characteristics obtained for OA and AZA1 at the low levels were good with regard to accuracy, repeatability and sensitivity (Table 4). Therefore, if in the future it is decided to lower the permitted levels for OA and AZA1, this method is capable of analysing these toxins with a high degree of confidence.

Application of the method to the routine monitoring programme in the Netherlands

During 2007 and 2008 a total of 623 shellfish samples that were collected in the Dutch monitoring programme were analysed by the rat bioassay as well as by the LC-MS/MS method. The monitoring included 491 mussel (M. edulis), 43 oyster (C. gigas), 41 cockle (C. edule) and 48 clam (E. directus) samples. All samples gave negative results with the rat bioassay. With LC-MS/MS low levels of OA were detected in 37 mussel samples from the Wadden Sea during the 2007 season. These levels were above the limit of detection of $1.9 \mu \mathrm{g} \mathrm{kg}^{-1}$ (signal-to-noise ratio of 3 for the strongest transition). In Fig. 3 the maximum concentrations
Fig. 3 Maximum concentrations of $\mathrm{OA}$ equivalents found in shellfish (mussels) taken from production area's in the Dutch Wadden Sea in 2007. EFSA European Food Safety Authority, $L O Q$ limit of quantitation, $L O D$ limit of detection

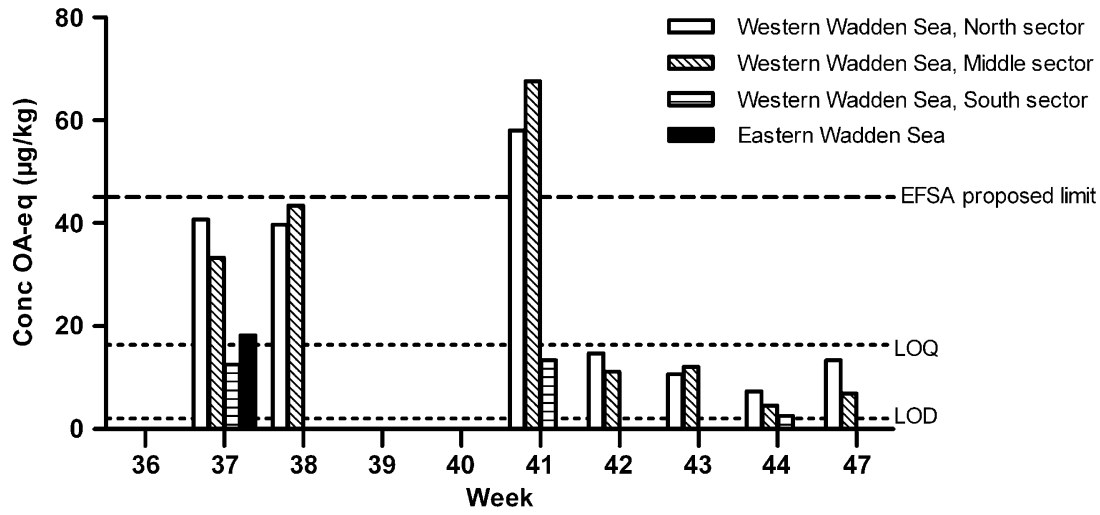


found in the specific areas are given. OA concentrations found above the limit of quantitation [signal-to-noise ratio of 6 $\left(16.4 \mu \mathrm{g} \mathrm{kg}^{-1}\right)$ for the weakest transition] ranged from 18.2 to $67.5 \mu \mathrm{g} \mathrm{kg}^{-1} \mathrm{OA}$. These concentrations were well below the current permitted level but some exceed the safety levels proposed by the EFSA. These results indicate that if the regulatory limits are lowered, animal tests such as the rat bioassay will lack sensitivity to meet these limits. Spirolides (SPX1) were the only other toxins that were found in the Dutch shellfish harvesting areas. In 2007 and 2008, SPX1 was detected in 15 mussel samples above the limit of quantitation $\left(1.6 \mu \mathrm{g} \mathrm{kg}^{-1}\right)$, ranging in concentration from 2.3 to $9.6 \mu \mathrm{g} \mathrm{kg}^{-1}$.

\section{Conclusion}

A recently developed LC-MS/MS method was validated, both in combination with and without SPE purification, using European Commission Decision 2002/657/EC as a guideline. MMS were used instead of spiking standards in methanol to construct calibration curves. The use of MMS largely eliminates matrix effects (ion suppression/enhancement).

The method performed very well for the parameters investigated. Only minor differences were observed between the crude extract and the SPE-purified extract. The largest difference observed was the change in sensitivity that occurred during analysis of the crude extracts. For larger series (more than 20 samples) it is advised to incorporate an SPE clean-up step, although this will lead to a more time-consuming method. Furthermore, it was shown that MMS in blank mussel extracts can be used to quantify other matrices such as oyster, cockle and clam. The species differences did not have a significant effect on the method. The validated method also performed well at low concentrations for OA and AZA1. Therefore, we recommend the use of this method for the analysis of lipophilic marine toxins instead of the currently used, less sensitive and animal unfriendly mouse and rat bioassays.

Acknowledgements This research was undertaken with the financial support of the Dutch Ministry of Agriculture and of the European Commission, within the Sixth Framework project 'BIOTOX: Development of cost-effective tools for risk management and traceability systems for marine biotoxins in seafood' contract no. 514074 (http://www.biotox.org).

Open Access This article is distributed under the terms of the Creative Commons Attribution Noncommercial License which permits any noncommercial use, distribution, and reproduction in any medium, provided the original author(s) and source are credited.

\section{References}

1. Gerssen A, Pol-Hofstad IE, Poelman M, Mulder PPJ, van den Top HJ, de Boer J (2010) Toxins 2:878-904

2. Cembella AD, Lewis NI, Quilliam MA (2000) Phycologia 39:67-74
3. Rundberget T, Sandvik M, Larsen K, Pizarro GM, Reguera B, Castberg T, Gustad E, Loader JI, Rise F, Wilkins AL, Miles CO (2007) Toxicon 50:960-970

4. Ciminiello P, Dell'Aversano C, Fattorusso E, Forini M, Magno S, Guerrini F, Pistocchi R, Boni L (2003) Toxicon 42:7-14

5. James KJ, Saez MJF, Furey A, Lehane M (2004) Food Addit Contam A 21:879-892

6. Klontz KC, Abraham A, Plakas SM, Dickey RW (2009) Ann Intern Med 150:361

7. Yasumoto T, Murata M, Oshima Y, Matsumoto GK, Clardy J (1984) In: Ragelis EP (ed) Seafood toxins: based on a symposium at the 186th meeting of the American Chemical Society, Washington, D.C., August 28 - September 2, 1983. American Chemical Society, Washington. pp 207-214

8. James KJ, Lehane M, Moroney C, Fernandez-Puente P, Satake M, Yasumoto T, Furey A (2002) Food Addit Contam A 19:555-561

9. Paz B, Daranas AH, Norte M, Riobo P, Franco JM, Fernandez JJ (2008) Mar Drugs 6:73-102

10. Richard DJA, Arsenault E, Cembella AD, Quilliam MA (2000) In: Hallegraeff GM, Blackburn SI, Bolch CJ, Lewis RJ (eds) Proceedings of the 9th conference on harmfull algal blooms, Hobart, Australia, pp 383-386

11. Miles CO, Wilkins AL, Munday R, Dines MH, Hawkes AD, Briggs LR, Sandvik M, Jensen DJ, Cooney JM, Holland PT, Quilliam MA, MacKenzie AL, Beuzenberg V, Towers NR (2004) Toxicon 43:1-9

12. Commission E (2004) Off J Eur Communities L 226:22-82

13. Alexander J, Audunsson GA, Benford D, Cockburn A, Cradevi J-P, Dogliotti E, Domenico AD, Fernandez-Cruz ML, Fink-Gremmels J, Furst P, Galli C, Grandjean P, Gzyl J, Heinemeyer G, Johansson N, Mutti A, Schlatter J, van Leeuwen R, van Peteghem C, Verger P (2008) EFSA J 589:1-62

14. Alexander J, Benford D, Cockburn A, Cradevi J-P, Dogliotti E, Domenico AD, Fernandez-Cruz ML, Fink-Gremmels J, Furst P, Galli C, Grandjean P, Gzyl J, Heinemeyer G, Johansson N, Mutti A, Schlatter J, van Leeuwen R, van Peteghem C, Verger P (2008) EFSA J 723:1-52

15. Alexander J, Benford D, Cockburn A, Cradevi J-P, Dogliotti E, Domenico AD, Fernandez-Cruz ML, Fink-Gremmels J, Furst P, Galli C, Grandjean P, Gzyl J, Heinemeyer G, Johansson N, Mutti A, Schlatter J, van Leeuwen R, van Peteghem C, Verger P (2009) EFSA J 1109:1-47

16. Alexander J, Benford D, Cockburn A, Cradevi J-P, Dogliotti E, Domenico AD, Fernandez-Cruz ML, Fink-Gremmels J, Furst P, Galli C, Grandjean P, Gzyl J, Heinemeyer G, Johansson N, Mutti A, Schlatter J, van Leeuwen R, van Peteghem C, Verger P (2008) EFSA J 907:1-62

17. Chapela MJ, Reboreda A, Vieites JM, Cabado AG (2008) J Agric Food Chem 56:8979-8986

18. Commission E (1986) Off J Eur Communities L 358:1-28

19. Vieytes MR, Fontal OI, Leira F, de Sousa JMVB, Botana LM (1997) Anal Biochem 248:258-264

20. Briggs LR, Miles CO, Fitzgerald JM, Ross KM, Garthwaite I, Towers NR (2004) J Agric Food Chem 52:5836-5842

21. Fux E, McMillan D, Bire R, Hess P (2007) J Chromatogr A 1157:273-280

22. McNabb P, Selwood AI, Holland PT (2005) J AOAC Int 88:761-772

23. Stobo LA, Lacaze JPCL, Scott AC, Gallacher S, Smith EA, Quilliam MA (2005) J AOAC Int 88:1371-1382

24. Gerssen A, Mulder PPJ, McElhinney MA, De Boer J (2009) J Chromatogr A 1216:1421-1430

25. Gerssen A, McElhinney MA, Mulder PPJ, Bire R, Hess P, De Boer J (2009) Anal Bioanal Chem 394:1213-1226

26. Goto H, Igarashi T, Yamamoto M, Yasuda M, Sekiguchi R, Watai M, Tanno K, Yasumoto T (2001) J Chromatogr A 907:181-189

27. Mountfort DO, Suzuki T, Truman P (2001) Toxicon 39:383-390

28. Commission E (2005) Off J Eur Communities L 338:40-41

29. Commission E (2002) Off J Eur Communities L 221:8-36

30. Commission E (1996) Off J Eur Communities L 125:10-32

31. Horwitz W, Albert R (2006) J AOAC Int 89:1095-1099 